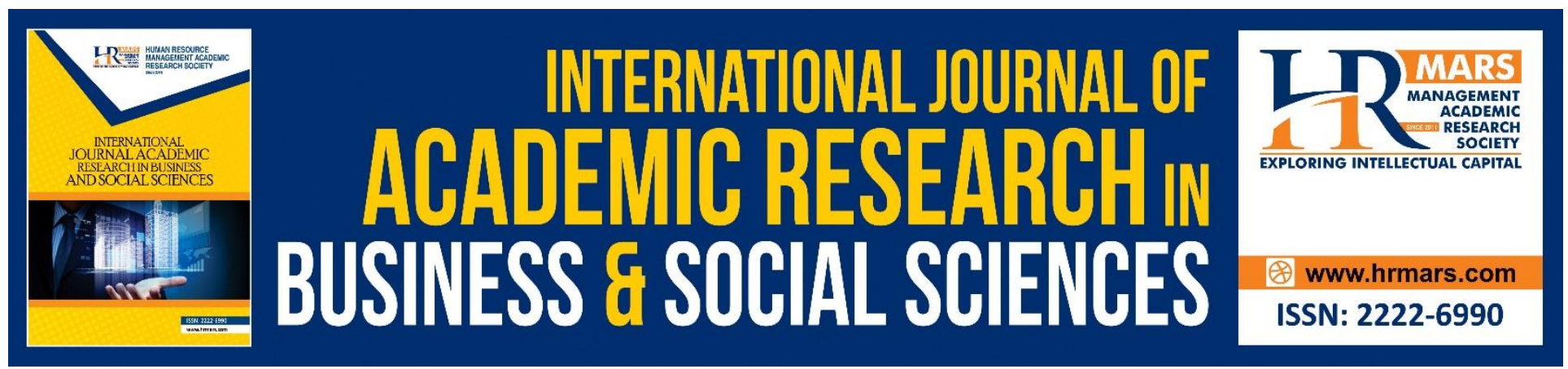

\title{
Malay Customs According to Islamic Perspective
}

\section{Basri Ibrahim, Fauzi Yusof, Wan Saifudin Wan Hasan}

To Link this Article: http://dx.doi.org/10.6007/IJARBSS/v8-i10/4743

DOI: $10.6007 /$ IJARBSS/v8-i10/4743

Received: 16 Sept 2018, Revised: 11 Oct 2018, Accepted: 21 Oct 2018

Published Online: 31 October 2018

In-Text Citation: (Ibrahim, Yusof, \& Hasan, 2018)

To Cite this Article: Ibrahim, B., Yusof, F., \& Hasan, W. S. W. (2018). Malay Customs According to Islamic Perspective. International Journal of Academic Research in Business and Social Sciences, 8(10), 380-400.

\section{Copyright: (C) 2018 The Author(s)}

Published by Human Resource Management Academic Research Society (www.hrmars.com)

This article is published under the Creative Commons Attribution (CC BY 4.0) license. Anyone may reproduce, distribute, translate and create derivative works of this article (for both commercial and non-commercial purposes), subject to full attribution to the original publication and authors. The full terms of this license may be seen

at: http://creativecommons.org/licences/by/4.0/legalcode

\section{Vol. 8, No. 10, 2018, Pg. 380 - 400}




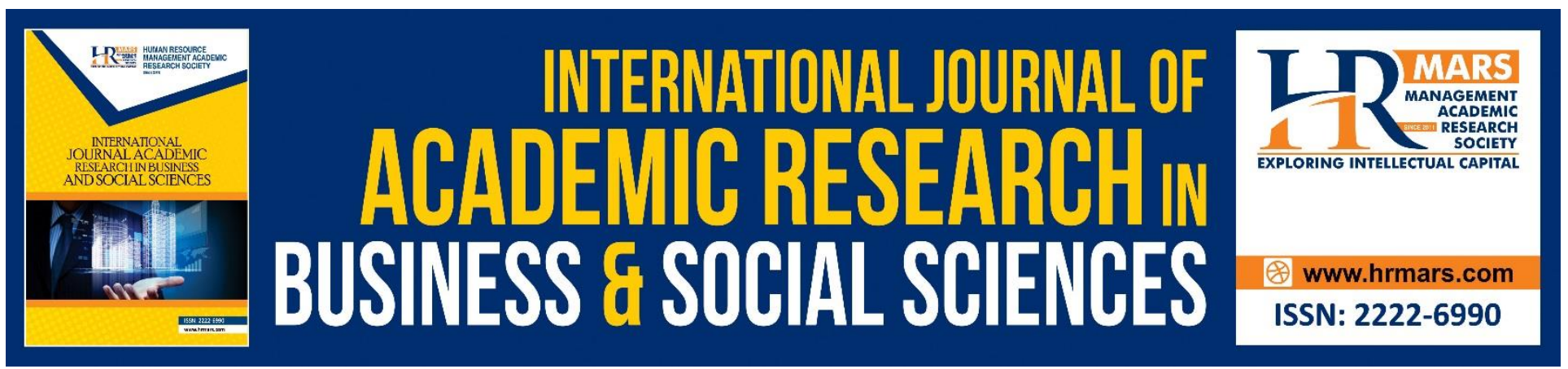

\title{
Malay Customs According To Islamic Perspective
}

\author{
${ }^{1}$ Basri lbrahim, ${ }^{2}$ Fauzi Yusof, ${ }^{3}$ Wan Saifudin Wan Hasan \\ ${ }^{1}$ Global Wisdom Academy, Universiti Islam Malaysia, Cyberjaya, Malaysia. \\ ${ }^{2}$ Fakulty of Islamic Contemporary Studies, Universiti Sultan Zainal Abidin, Terengganu, Malaysia. \\ ${ }^{3}$ Fakulty of Islamic Contemporary Studies, Universiti Sultan Zainal Abidin, Terengganu, Malaysia. \\ Corresponding Author: drbasr67@gmail.com
}

\begin{abstract}
It can be said that each race in the world has its own customs. That also applies to Malay community. They are rich in various customs such as adat sebenar (genuine customs), adat teradat (communal customs), adat yang diadatkan (accustomed customs) and adat istiadat (ceremonial customs). Within them, lies the expression which becomes the treasure of the race and is built from the past life experience. Customs in Malay community is a synonymous element with the life of the community. On the existence of customs in Malay community, some of the customs do comply with the teachings of Islam and some do. With regard to it, this writing aims to discover the extent of accuracy and conflict between some of the adat teradat and adat yang diadatkan within Malay community with the teachings of Islam. With that, the good custom can be continued and the conflicting one needs to be fixed or alternated with more suitable one according to Islamic teachings. The method used in this writing was based on qualitative method. Data were collected from library study focusing on books related to customs, al-Qur'an, al-Sunnah (Prophet's traditions), tafsir (interpretation of al-Qur'an), syarah sunah (discussion of the Prophet's traditions) and also major books of Islamic jurisprudence. This study found that the customs related to visit and coming to other people's house do not contradict with the teachings of Islam. Customs regarding pregnancy also do not conflict with Islamic teachings but the implications raised should be referred to the specialists. Customs on the birth do contradict with Islam. Some customs related to marriage are aligned with Islamic teachings and some are not. Lastly, all customs regarding death are not compatible with Islamic teachings and need to be revised towards a more Islamic one.
\end{abstract}

Keywords: Adat Teradat (communal customs), Adat Yang Diadatkan (Accustomed Customs), Alternative, Fiqah Islamic Jurisprudence, Marriage.

\section{Introduction}

Malay community is the largest population in Southeast Asia which exceeds 300 million people. This community occupies countries such as Indonesia, Malaysia, Singapore, Southern Thailand, Southern Philippines, Maldives and others. Malay community has a lot of their own unique taboos as other 
races in the world. Taboos become one of the heritages in the culture of Traditional Malay community that own a very high value. Within them, lies the expression which becomes the treasure of race, built from past life experiences. These experiences would become examples for life nowadays. Taboos of traditional Malay people are beliefs of ancient Malay community regarding customs and inherited culture of ancestors. Most of the taboos are inherited verbally (Anis, 2014).

Customs, taboos and tips in Malay community are a synonymous element with the life of the community. The position of tips, customs and taboos is closely related to the fatwa produced by mufti. The existence of tips, customs or taboos in Malay community which have been given fatwa; some of them are not compatible with Islamic sharia, some are. While discussing on the tips and taboos in Malay community, it actually relates to Malay customs. Customs in Malay community; some are acceptable and some should be rejected. These customs encompass practices since a birth until a death. Among the customs in Malay community is birth reception customs, post-pregnancy customs, circumcision, marriage and others (Kamarudin \& Liki, 2008).

Malay community is rich with its own customs and taboos. Custom is a community element which is inherited traditionally from their ancestors to retain the traditions of their race. It is also the unwritten laws or righs of a certain community (Irma, 2016).

A question rises that all Malay customs do comply with Islamic teachings so that they qualify their continuity by Malay people or some do not? In conjunction with that, this article is brought forward to aiming to explain on Malay customs from Islamic perspective to see their extent of accuracy and compliance with Islamic teachings. With that, Muslim community in Malaysia can differentiate between the complying one and the not complying one. The complying one should be continued, while the contradicting one should be avoided and Islamicised that it will be aligned with Islamic teachings. A lot of writings on Malay customs have been done before. Among them are Kamarudin dan Liki (2008) Adat, Pantang Larang, Petua Dan Fatwa Dalam Masyarakat Melayu, Mohd Rosli (2005), Teromba, Anis (2014), Pantang Larang Dalam Kalangan Orang Melayu: Analisis Dari Perspektif Teori Spb4k, Tonel, (1920). Adat-istiadat Melayu, Irma (2016). 27 Adat Resam Dan Pantang Larang Melayu, Haslina (2004) Adat Melayu sebagai sumber hukum : penilaian dari perspektif teori al-'Urf Wa al-'Adah and others. However, writings on Malay customs from Islamic perpective are still few. Due to that, writing should be done to see the extent of Malay customs that comply with Islam to be continued, and the Malay customs that do not comply with Islam to be discontinued.

\section{Research Methodology}

Writing method used was based on qualitative study, in which data were collected from books discussing on Malay customs, and then comparison was done with evidences in al-Qur'an, al-Sunnah, books of tafsir, syarah sunnah and also opinions of scholars in the famous books of Islamic jurisprudence. Data collected were then analysed and discussed according to comparison method with the evidences from al-Qur'an and al-Sunnah. 


\section{Findings}

Malay community admits that its main self-identities are Malay customs, Malay language, and religion of Islam. With that, an individual who claims to be a Malay person should practise Malay customs, speak Malay language, and embrace Islam. Among these three main identities of Malay people, the main pillar is the religion of Islam as it is the source of Malay customs. In Malay language, there are many expresstions, proverbs, similes, rhymes, poems, and others that integrate the norms of politeness and interaction manners of Malay people (Ghalib, 2005).

\section{Definition of Adat (Customs)}

Etymologically, adat derives from Arabic word which means "routine". It is also defined as an action done frequently and then becomes a regular and respected routine. The routine becomes a custom. Customs are routines that rise and form from a community or district which is regarded as having dignity, honoured and obeyed by the practising community (Samhis, 2016).

Customs are kebiasaan (routines), resam (common law), lembaga (bodies), peraturan (rules), and norma-norma (norms) which are upheld by the community group. in ancient Malay language, customs refer to rules or laws of customs including social, political, economic and and even maritime aspect. When hukum adat (customary law) is mentioned, it refers to the law which is based on old routines or traditional routine. Orang beradat (person with custom) refers to a good person or a person with race. Raja beradat (king in custom) means a king on throne before the prominent people, while the term orang yang tidak beradat (person without custom) means a rude person or a bad person (https://ms.wikipedia.org. 2018).

Custom also means a regular rule practiced since the ancient time. When adat resam (manner) is mentioned, it refers to regular custom practiced by a certain tribe, district or others (http://prpm.dbp.gov.my, 2018).

In Ensaiklopedia Umum Indonesia (Indonesian General Encyclopedia), "adat" (custom) is meant by the arrangement of certain aspects of people's life which arises from the attempt of people in a certain district formed in Indonesia as a social group to organise the behaviours and manners of the community members. In Indonesia, the organising of aspects in people's life becomes the law determination that binds and it is mentioned as customary law (Yayasan Kanisius, 1973).

If the definition of custom is looked, it refers mostly to routine, common law, body, rule, law and norm upheld by the community group. In ancient Malay language, custom refers to law or customary law encompassing social, political, economic and even maritime aspect.

\section{Objectives of Custom}

Customs and taboos of Malay people are aiming to educate community to instill good values to be practised in life. Element of education, either directly or indirectly, is implemented in taboos of Malay community. Taboos are verbal disciplines practised by traditional Malay people. Taboos are still 
among Malay people nowadays even though the practice is fading away. Ancient old people always reminded their descendants of not breaching the taboos. Breaching taboos is considered as disobeying old people's advice. Taboos are directed towards all levels of community including pregnant women, babies, children, women and also men (Anis, 2014:78).

Customs and taboos also aims to create a peaceful community. It is a direct or indirect educational tradition to make exist the serenity of common people (Ramli, 1999).

\section{Division of Customs}

Malay people classify customs into four main parts which are adat sebenar (genuine custom), adat yang teradat (communal custom), adat yang diadatkan (accustomed custom) and adat istiadat (ceremonial custom). Based on this division, the usage of sayings such as 'adat menang ada kalahnya' (it is a custom where a winner present in the presence of a loser), 'biar mati anak jangan mati adat' (son may die, but the custom should not fade), 'tak tahu adat' (custom-ignorant) and adat istiadat (ceremonial custom) have different meanings between each other. Confusion on the real understanding of the custom always puts Malay custom to be considered as outdated and contradicting with Islamic teachings (Haslina, 2004).

Adat sebenar adat exists according to observation to the natural occurrences happening to the circle of life. Natural attributes existing in a certain thing or situation become the base of differentiation between it and other natural element such the custom of cock to crow, the custom of water to wet, and others. Adat yang teradat is a custom built according to relationship between the surrounding community. To make real the comfort of community life, a rule must be formed. Adat yang diadatkan refers to regular practice enforced in the community for the sake of community harmony and peace and it evolves with time (Zainal, 1996). Ceremonial custom refers to the regular ceremony in the community and it has certain principles to be followed. It is also exposed to the changing time (Kadir, 2000). In this writing, the discussion is focused only on some of adat yang teradat and adat yang diadatkan involving customs related to visit and coming to tother people's home, birth, marriage and death.

\section{Relationship Of Malay Customs And Islamic Laws}

Malay customs began to undergo islamisation process by means of modification according to Islamic laws after Islam entered Melaka in the late $14^{\text {th }}$ century. According to Tonel (1920), Malay customs at the beginning were based on Malay ceremonial customs which were practised in state of Temasik, Bentan and Melaka. In Melaka era, the customs were islamised due to king's acceptance of Islam. The determination of sharia laws was considered as customs obeyed by community members, until a difficulty happened in differentiating between the pure customs and the ones coming from sharia laws.

\section{Customs According to Islamic Perspective}

In Islam, the discussion of customs and taboos is categorised into discussion of uruf (customs) which is always debated in usul fiqh (principles of Islamic jurisprudence). Uruf according to Zaidan (1976) 
INTERNATIONAL JOURNAL OF ACADEMIC RESEARCH IN BUSINESS AND SOCIAL SCIENCES

Vol. 8, No. 10, Oct. 2018, E-ISSN: 2222-6990 @ 2018 HRMARS

means a routine of community and it is always practised in their daily life in verbal or action form. Customs are sometimes in the form of action and sometimes verbally. They also include general and specific customs and, good and bad or spoilt customs.

\section{Customs in the Form Of Action And Words}

Practical uruf is the custom involving a practise which is always implemented by community such as trade by pointing at the price tag without mentioning the price of desired item, division of dowry into advance dowry and delayed dowry, usage of public toilet without limitation of time and water usage, usage of house appliances and shoes, food preparation as a sign of permission to enjoy the food and others (Zaidan,1976).

Customs in verbal form are customs involving frequent words used to indicate certain meanings and not regular literal meaning such as the word child (walad) that usually means son excluding the daughter, meat (al-Lahm) which involves all meat besides fish, the word al-Dabbah which refers to four-legged animals, in spite of the real meaning which refers to all moving animals on earth.

Both customs are further divided into general and specific categories. They become general customs when they are propagated and practised widely and comprehensively by the community occupying the Islamic countries. They become specific customs if they are only spread in certain countries only without involving other countries or only involve certain profession. One of the specific customs practised in country of Iraq is the division of dowry into advance dowry and delayed dowry. One of general verbal customs is the usage of word al-Dabbah to mean four-legged animal excluding human, even though the word is also linked to human according to application of al-Qur'an and the usage of talak word to indicate the dissolution of marriage.

Example of specific verbal customs is the words used by scholars in their expertises, words used in industrial field and others (Zaidan, 1976).

\section{Good and Bad (Spoilt) Customs}

Good customs refer to practices of community which do not contradict with any sharia evidence, do not permit which the forbidden, and do not void mandatory practice in Islam such as community custom to use al-Istisna' contract (a contract involving the making of ordered item involving delivery not at the contract time but according to agreed time between the seller and the buyer, while the payment of order is submitted completely). That also goes to the custom of dividing the dowry into advance dowry and delayed dowry, the sending of bride too the groom's house is done when the groom has paid the whole dowry and the consideration of items sent to bride-to-be during proposal involving jewelleries and clothes as presents and not as part of dowry.

Bad customs refer to customs practised by community which contradict with sharia evidence, permitting the forbidden and voiding the mandatory such as customs involving misconducts which 
occur in celebration of Prophet's birth or in feast held in conjunction with someone's death, involving with riba-based contracts and contracts with element of betting and gambling (Khallaf,1957).

According to Zaidan (1976), among the conditions to be fulfilled to ensure the acceptance of a custom is that it does not contradict with sharia evidence, does not void the main benefit and does not bring harm to the community.

\section{Position of Good Custom}

Good customs must be celebrated by the scholars who do ijtihad (making opinion) in the field of law and judiciary, as any matter that becomes good custom to the community, is counted as a need and a necessity of their life. The sharia itself celebrates the good custom in Dark Age Arab such as the compulsion of paying the fine (al-'Aqilah) which is burdened upon the family of murderer in the murder case done to someone not guilty, the putting of sekufu (alignment) condition in marriage and others. Scholars explain that custom is the law that becomes the reference in judiciary (syari'ah muhkamah). Imam Malik himssef did a lot of ijtihad in the production of laws to the practices of Madinah citizens. Imam Abu Hanifah and his students contradicted each other in the opinions regarding some sharia laws due to the difference in custom of local people. Meanwhile, Imam alSyafi'i during the transfer Egypt, changed his ijtihad regarding a few of sharia laws decided by him in Baghdad, which is known as qawl qadim (old opinion) to qawl jadid (new opinion) to acknowledge the custom practised by people in Egypt which differed from people in Baghdad.

On the other hand, bad or spoilt custom cannot be taken into account at all due to its contradiction with sharia and cancellation of any sharia law. For example, if the community has already got used to business contract based on riba, gharar (fraud) or betting, such contracts do not impose any influence in its permissibility in sharia. Indeed, in the man-made law itself, there is no custom contradicting with constitution and general laws (Khallaf, 1957).

\section{Analysis Of Malay Customs From Islamic Perspective}

Due to the fact that Malay race involves a group of large race and encompasses a population of more than 300 millions people, it must have various customs practised regardless of its accountability based on Islam. before this, it has been explained that customs practised by Malay community have already undergone islamisation process since the existence of Melaka Malay, but it is not comprehensive. The customs practised in Malay world are also dissimilar. Some customs practised in Malaysia are not same wih customs in Indonesia, Southern Thailand, Mindanao Achipelago, Philippines and others. However, it is not the objective of this paper to discuss the dissimilarity of customs in the practice of Malay community and factors behind the dissimilarities. Instead, in this paper, the discussion is focused on some of choosen Malay customs practised in Malaysia to see the extent of their accuracy or contradiction with the holy Islamic teachings.

\section{Customs of Visit and Coming to Other People's House}

Among the customs practised by Malay community regarding visit and coming to other people's house are: 
INTERNATIONAL JOURNAL OF ACADEMIC RESEARCH IN BUSINESS AND SOCIAL SCIENCES Vol. 8, No. 10, Oct. 2018, E-ISSN: 2222-6990 @ 2018 HRMARS

a. When arriving at the visited house, the regard must be addressed in expression of "Assalamualaikum".

b. Before entering the house of Malay people, the visitor must take off the shoes.

c. If there is other visitor at the time, the later visitor should introduce himself and bow a little bit as a sign of respect while shaking hand.

d. When someone wants to pass by a group or gathering of people, he must lower his head a little bit and extend one of his hands. The suitable expressions for this intention are 'maafkan saya (excuse me), tumpang lalu (requesting a pass), minta jalan (requesting a way)'.

e. The visitor and homeowner should duduk bersila (sitting with legs crossed each other). For male, he should bersila (sit with crossed legs), and for female, she should bersimpuh (sit with the legs bend to the back). While sitting on the chair, it is considered as rude if someone crosses his legs exposing the sole, straightening the legs or opening wide the legs.

f. When the homeowner serves the food, it is impolite to reject it. Even though the guest is full already, he must taste the served food a little bit.

g. Girls must scoop the rice into the plate of older people. Do not scoop too much or too little, be moderate. Let older people get their food first and then the younger as it is rude to let older people to get the remnants of younger people. Some people set a rule in which younger people must eat separately from older people or older people should eat first. However, this practice is not too suitable if we want to instill friendliness and sense of family among the children.

h. Getting the closest serving and reaching for the farther food which is hard to reach. If intending for farther food, get help from neighboring person.

i. While passing and receiving the food, the elbow or the wrist should be supported by the other hand. While scooping the gravy or rice, use left hand so that the spoon or ladle will not be dirty. The noise while scooping is considered impolite and rude. Do not talk while eating and much more when the mouth is full of food.

j. If talking, make sure that you are not raising undesirable matters that may distort the appetite or cause a quarrel with the guest or other people (http://www.jkkn.gov.my, 2018).

If part (a) until (m) are observed, they indicate good customs which conform with the traditions of Prophet p.b.u.h. in entertaining the guest and his encouragement in serving the guest. Addressing salam (regards) while visiting other people's house is encouraged and it becomes a Prophet's tradition which was explained in a hadis (narration) narrated by Muslim. the practice of taking off the shoes is to ensure that the house is not disgraced by the dirt and feces. It is a good custom even though it has never been known before that Prophet p.b.u.h. would take off sthe slippers or shoes while entering the house. It is due to the probability that the house customs and cultures are different between Arabs and Malays.

Introducing one's self to the guest in a house and shaking hands are good customs. Self introduction for example, was done by the women during the time of Prophet p.b.u.h., as stated by a hadis narrated by Abu Sa'id r.a: 
INTERNATIONAL JOURNAL OF ACADEMIC RESEARCH IN BUSINESS AND SOCIAL SCIENCES

Vol. 8, No. 10, Oct. 2018, E-ISSN: 2222-6990 (C) 2018 HRMARS

Means: Zainab ithe wife of ibn Mas'ud r.a sought permission to meet Rasulullah. At that time, Rasulullah p.b.u.h. was told that: This is Zainab. Rasulullah said: Which Zainab? It was said to Prophet: Wife of Abdullah bin Mas'ud. Said Rasulullah; Yes. Allow her, and then Zainab was allowed to meet Prophet p.b.u.h. to ask about the priority of giving alms (which should be given by a wife).

(Sahih: al-Bukhari:1369)

While shaking hands is in the hadis narrated by al-Barra' bin Azib, explaining that Rasulullah SAW said:

Means: There is no two Muslims meeting each other and shaking hands, except that they will be bestowed with forgiveness for both of them until they separate

(Hasan Gharib: al-Tirmizi:2651)

The action of passing by a group or gathering of people, and lowering the head a bit and extending a hand while saying 'maafkan saya (excuse me), tumpang lalu (requesting a pass), minta jalan (requesting a way)' are good customs and praised disposition. Rasulullah p.b.u.h. forbid individual of showing rudeness in a gathering. For example, stepping over other people's necks, including in a coming to the mosque to perform prayer. In a hadis narrated by Abdullah bin Busr explaining that:

Means: A man stepped over the people's necks on Friday while Prophet p.b.u.h. was giving sermon. Prophet p.b.u.h. said: Please be seated. Truly you have harmed other people.

(Sahih: Abu Dawud;943)

The action is only allowed in a criticaland dire need. In a hadis narrated by Uqbah r.a explaining that:

Means: I have performed Asar prayer behind Prophet p.b.u.h. in Madinah. Prohet gave salam and got up quickly and stepped over people's necks heading to the room of one of his wives. The people were shocked with his action. After that, he got out meeting them and seeing them confused as he left them so quickly. He said: I remembered a block of gold with us which has not been cleaned yet. I don't like it being so long in our keeping. I command that it should be divided to the rightful one.

(Sahih: al-Bukhari:851)

According to Uthaimin (t.th), the hadis explains the permissibility of stepping over other people's necks after the performing of prayer, if there is dire need insisting that, as after the performing of prayer, the people should not stay at their place. Instead, they should diperse. 
INTERNATIONAL JOURNAL OF ACADEMIC RESEARCH IN BUSINESS AND SOCIAL SCIENCES

Vol. 8, No. 10, Oct. 2018, E-ISSN: 2222-6990 C 2018 HRMARS

Stepping over other people's necks in the mosque before the performing of prayer is not allowed at all, as it obviously harms people.

Duduk bersila with the guest is a good custom. Prophet p.b.u.h. himself duduk bersila with his guest who was the angel Jibril which imposed as a man in white clothes to ask him about Islam, Iman (faith) and Ihsan (sincerity). In the hadis narrated by Umar bin al-Khattab r.a saying:

Means: One day, we were with Rasulullah p.b.u.h. when there was a man among us with very white clothes and very black hairs. There was no sign of travel on him and no one among us who knew him until he sat facing Prophet p.b.u.h. He leaned his knees onto Prophet's knees and put his hands onto Prophet's laps.

(Sahih: Muslim:9)

It is not good for guest to reject the served food by the homeowner. Even he is full already, he should taste a bit of it. In Islam, a person is taught to begin by eating the served food, even though he has eaten and even at the time of prayer, as said in hadis narrated by $A^{\prime}$ isyah r.a:

Means: There is no prayer while the food is served and while holding the need of urinating and defecating.

(Sahih: Muslim:869)

While discussing the hadis, al-Abadi $(1415 \mathrm{H})$ explained that when the food is served and someone's soul is craving for the food, the prayer should not be performed yet. It is a general command either for compulsory prayer or optional prayer involving hungry or not hungry people. Indeed, the status of prayer at that time is discouraged due to the condition of the soul which is craving for the served food.

Meanwhile, girls are told to scoop rice into the plate of older people with a moderate rate. Oldeer people will get the food first and then the ounger as it is rude to let older people to eat remnants of younger people. This is the custom of respecting older people which is so encouraged in Islam. Rasulullah p.b.u.h. said in the hadis narrated by Amru bin al-As r.a:

Means: Anybody who does not show compassion to the children and does not know how to respect the older people, he is not among us.

(Sahih: al-Bukhari, al-Adab al-Mufrad: 354)

The need to get the closer food first is a good custom and disposition and if the person wants to get the farther food, he can get help from the neighbouring person. In this matter, Prophet p.b.u.h. said in hadis narrated by Umar bin Abi Salamah r.a:

Means: O child, say Allah's name before eating, eat wth the right hand and eat the closer food first. 
INTERNATIONAL JOURNAL OF ACADEMIC RESEARCH IN BUSINESS AND SOCIAL SCIENCES

(Sahih: al-Bukhari:4957)

Talking while eating is permitted but only it only involves good matters and not backbiting or insulting others. The mentioned custom is a good custom and a good disposition. Rasulullah p.b.u.h. said in a hadis narrated by Abu Hurairah r.a:

Means: Whoever believes in Allah and the Hereafter, must utter good words or just be silent.

(Sahih: al-Bukhari:6475)

\section{Customs Regarding Pregnancy}

Among customs regarding pregnancy and birth are:

a. Cannot insult or talk about disfigurement, as it may cause deformity to the born baby.

b. Cannot hit, abuse or injnure animals, as it may cause disfigurement the born baby.

c. Cannot use nail, chisel, fishhook or slaughter animals, as the baby will have cleft lip.

d. Cannot look at something weird, as it may cause kenan (resemblance).

e. Cannot eat squid, as the umbilical cord will suffocate the baby.

f. Cannot drink sugar cane and coconut drink and cannot eat pineapple, as it may cause abortion.

g. Cannot look at eclipse, as baby will have dark spots.

h. Cannot sleep until midday, as baby's head will swell (Irma, 2016).

If the statements above from (a) until (h) are looked, it is clearly found that it aims to take care of pregnant mothers and the pregnancy from negative practices involving physical and spiritual aspects which can affect the mother and the gestated baby. They all must be avoided by pregnant mother. In Islam, everything that may harm someone's life physically or spiritually must be avoided, based on the hadis narrated by ibn Abbas, explaining that Rasulullah p.b.u.h said:

Means: There would be no harm and cannot do harm.

(Sahih: Majah: 2332)

Besides that, a Muslim cannot insult others, uttering rude and bad words and also curses. It is in conjunction with a hadis:

Means: Muslim is not a person who likes to insult, curse, do disgusting things and utter dirty words.

(Hasan Gharib: al-Tirmizi:1900)

However, the risks arising from doing the above forbidden actions are still not confirmed and cannot be acceptd. For example, insulting others will cause deformity to the baby, using nail and 
chisel will cause cleft lip to the baby, seeing something weird will cause disfigurement, sleeping in midday will cause the baby's head to swell, eating squid will cause the umbilical cord to suffocate the baby and others. This needs reference to the experts. Al-Qur'an explains that in facing an ignorant person, a reference to the experts is a must. Allah s.w.t said:

Means: And We did not send Messengers before you (O Muhammad), except that they were men, which We sent revelation to them. Hence, you must ask (O polytheists) the knowledgeable people of religion if you do not know.

(al-Nahl 16:43)

\section{Customs Regarding Birth}

Among customs regarding birth are:

a. Melenggang perut (Stomach rolling). This custom is done to the woman bearing the first child in the pregnancy age of seven to eight months old. This ceremony is done by a midwife to get rid of jinx which will happen to the pregnant woman before the birth and to fix the position of baby in the womb.

b. Hanging a thorny pine leaf under the house and the chalk is crossed at certain places under the house of pregnant woman to avoid the disturbance of mystical creatures.

c. The placenta cannot be buried at exactly 12.00 at noon as it will lead to a stubborn child. It alsomust be buried with tamarind, salt, needle, book and pencel so that the child will be hardworking and clever. It also cannot be buried too deeply as the child's ability to speak will be delayed (http://www.jkkn.gov.my, 2018).

The custom of stomach rolling is not a custom found in Islam, although its objectives are good. If the objective is because the belief that the gestated baby will be safe, it may to shirk (God's association). If it is done to know the gender of the baby, it is not an accurate method. The safety of the baby in the carriage dependson the mother's health and the gender depends on Allah's decision. The field of medicine nowadays candetect the gender of the baby in the age of seven until eight months old but it still fails to detect the gender at early stage. It is all Allah's affair.

This custom is believed to contain elements of Hindu culture. Indian community also perform ceremonies such as stomach rolling which is 'valaikaapu' to bless the pregnant woman, celebrating her pregnancy and ensuring the safety of the pregnancy. It is also done to the woman with first-baby pregnancy and at the pregnancy age of seven until nine months old (Irma, 2016).

In Islam, Muslims are prohibited from performing the rituals practised by the people of other religion, as stated in hadis narrated by Ibn Umar r.a: Rasulullah s.a.w said:

Means: Whoever imitates the practice of a group, he falls into that group.

(Sahih:Abu Dawud:3512) 
INTERNATIONAL JOURNAL OF ACADEMIC RESEARCH IN BUSINESS AND SOCIAL SCIENCES Vol. 8, No. 10, Oct. 2018, E-ISSN: 2222-6990 ㄷ 2018 HRMARS

According to San'ani (1960,), the above hadis explains on person who imitates fasik (mischievous person), pagans and person of bidaah (innovation of worship practice) in performing specific practice performed by them in the aspect of clothing, vehicle and lifestyle. If the person intends the need of clothing as the Muslims, the intention may lead to kufr (disobedience). If not, it may not lead to disobedience but it is still rejected by Islam.

The gender of the baby is decided only by Allah s.w.t. Allah s.w.t said:

Means: To Allah is the ownership in the heavens and in earth; He creates whatever he wants; He awards daughters to whomever He wants; He awards sons to whomever He wants or He awards them both - daughters and sons, and He also makes whomever He wants to be barren. Truly, He is the All-knowing, and Omnipotent.

(al-Syura 42: 49-50)

To drive away disturbance from Satan and the unseen creatures, it can be done by reciting surah al-Baqarah and not by hanging thorny pine leaf and putting it under the house. In hadis narrated by Abu Hurairah r.a explain that Rasulullah p.b.u.h. said:

Means: Don't make your house as graveyard. Truly, Satan will run away from the house recited with surah al-Baqarah.

(Sahih:Ahmad:8681)

Human placenta is a part of human internal organs except that it comes out with the baby. As it is a part of human organs, it must be buried as proper as possible so that it will not stink and attract wild beasts to dig. This aligns with the status of human honoured by Allah s.w.t: Allah s.w.t said;

Means: And tryuly we honoured the sons of Adam; and We gave them the ability to use various vehicles in the land and the sea; and We bestowthem with bounties from good things and We prioritise them with the most of priority above many of the creations We created..

(al-Israk 17:70)

The burying of placenta should not involve several practice of taboos and superstitions, whichare not commanded by Islam to its people, but it must only be buried as usual.

\section{Customs Regarding Marriage}

Among customs of Malay community regarding marriage are:

a. The couple is not allowed to go out with the spouse before the marriage ceremony for 40 days to avoid community's insult and to guard the desire. it is also to create the sense of missing among the couple before the ceremony occurs. 
b. The couple is not allowed to go out freely to avoid being the victim of black magic.

c. Merisik (Spying). It is done to seek and observe the girl, and time and also the date of visit by man's representatives should classified (the real procedure). The objective is to make sure that the girl is still single and to investigat the background of the girl.

d. Proposal. If the girl is known to be single, the man's representative will set a date to send a convoy of proposal. The proposal affair must only be done by the closest family. In the process, both parties will negotiate to set a suitable date and time for engagement.

e. Berinai (henna wearing). Henna wearing is done at night before the marriage ceremony. The objectives of henna wearing are to get rid of catastrophe, clean the filthy matter and to make beautiful the bride-to-be. This ceremony is to symbolize the readiness of the couple to build an official relationship.

f. Merenjis (Sprinkling) or doing the tepung tawar. It is one of Malay customs in a marriage that still remains until today (Irma, 2016)

Prohibition in Islam to the future bride and groom from going out together is because it will expose the couple to adultery and other filthy actions prohibited in Islam. The prohibition is not only to the future couplebut it also goes to every unmarried man and woman in Islam. The prohibition of going out to the couple in the Malay custom is good and in accordance with al-Sunnah, but the prohibitionshould not be related to a certain duration such as for 40 days before the marriage ceremony, because sunnah did not determine the duration, but it is meant forever with exception in the accompany of mahram (relative). In a hadis narrated by ibn Abbas r.a, explaining that Rasulullah p.b.u.h. said:

Means: A man cannot be in privacy with a woman except with company of a relative.

(Sahih: al-Bukhari:4832)

Spying is a demand by sunnah Rasulullah p.b.u.h. in a hadis narrated by al-Mughirah bin Syu'bah r.a, explaining;

Means: He has proposed a woman. Rasulullah p.b.u.h. said: Look at the girl first, because by looking (spying), it will maintain the bond between the husband and wife.

(Hasan: al-Tirmizi:1007)

Same goes to the engagement, it also becomes a demand in Islam and sunnah Rasulullah p.b.u.h. In a hadis narrated by Fatimah binti Qais r.a explaining:

Means: She met Prophet p.b.u.h. and told him that Abu Jahm bin Huzaifah and Muawiyah bin Abu Sufyan proposed her. Prophet p.b.u.h. said: Abu Jahm is aman who never lifts his staff to the woman (bad-tempered) while Muawiyah is a poor man, without properties. But marry Usamah.

(Hasan Sahih: al-Tirmizi:1053) 
Henna wearing custom does not exist in Islam what more sunnah Rasulullah p.b.u.h., but Islam has never prohibited to decorate a mowan asa preparation to face the marriage world between the family members, as long as it does not use harmful substance it is not done exaggeratedly leading to a waste. In a hadis narrated by Abdullah bin Mas'ud r.a. explaining, Rasulullah p.b.u.h. said:

Means: Man who owns in his heart the feeling of arrogance as big as an atom will not enter paradise. A man said: There is a man who loves nice clothes and good slippers. Prophet p.b.u.h. said: Allah is beautiful and He loves beauty. Arrogance wipes out truth and invites hatred among people.

(Sahih: Muslim:131)

Sprinkling and doing tepung tawar to the couple on the altar is not in the teachings of Islam and in sunnah of Prophet p.b.u.h. It is influenced by Hindu religion, which is urged by the hadis to be avoided by Muslims. The ceremony of menepung tawar is wholly influenced and practised by Indian community which is believed to prevent bad things besides driving away Satan that leads to destruction of family happiness and disturbance to the couple. In Hindu community, sprinkling is not just a practice or custom, it is one of the teachings in their religion that permits the ceremony to remove jinx and bad luck from the couple.

On the other hand, most of Malay community belive that sprinkling ceremony in marriage is a symbol of family blessing to the couple with a hope the couple wil be happy forever. The sprinkling ceremony is done as a complement to the schedule of marriage ceremony. The practice is performed to cherish the ceremony besides strengthening the family bond and respecting the elders.

If it is done without any belief as above, it is still considered as bidaah (community innovation disallowed by Islamic laws) and the practice is rejected by Islam itself (http://www.alahkam.net,2003).

\section{Customs Regarding Death}

Among customs regarding death are:

a. Springkling flower-mixed water onto the grave after the burying of the dead.

b. Holding a kenduri arwah (feast of death) or tahlil ceremony on the first, third, $44^{\text {th }}$ and $100^{\text {th }}$ day after the death to deliver the reward of the deed to the dead.

c. Making decoration on the grave such as marble and widening the grave on the $100^{\text {th }}$ day after death.

d. Grieving for 40 days, and for the prominent people's death, specific clothes are to be worn by the living people (Irma, 2016). 
INTERNATIONAL JOURNAL OF ACADEMIC RESEARCH IN BUSINESS AND SOCIAL SCIENCES Vol. 8, No. 10, Oct. 2018, E-ISSN: 2222-6990 @ 2018 HRMARS

The practice of sprinkling the grave with water is not wrong. In al-Syafi'i sect, sprinkling water on the grave, putting pebbles and and stones on the head side and others are encouraged. This is based on hadis by al-Baihaqi put forward from hadis Jaafar bin Muhammad from his father:

Means: Prophet p.b.u.h. sprinkled water onto the grave of his son, Ibrahim. And he put pebbles and leveled it for a span.

(Daif: al-Baihaqi:6528)

However, it is a weak hadis. The main objective of sprinkling water onto the grave is to strengthen the soil of grave. It is not just al-Syafi'i sect who encourages the practice, indeed the scholars of Hanafi Hanbali sects also have the same opinion that pouring water onto the grave after burying is encouraged so that the soil will be tight and prevent from wind blowing. They are supported by Prophet's action on the graves of Sa'ad bin Mu'az and Uthman bin Maz'un. However, the conviction of some people who pour water on the grave that the water will benefit the dead, is an untruthful belief, and has no base (al-Mawsu'ah al-al-Fiqhiyyah, 1983).

Holding the feast of death or tahlil in conjunction with the death of someone does not exist in Islam. According to al-Zuhaili (2007), being busy preparing food, gathering and inviting people to taste the food on the first day, the first week, $40^{\text {th }}$ day and even a year after the death, is a bidaah which should be avoided. Instead, sunnah practice is that the relatives of the dead and the neighbours prepare the food to be given to the family of the dead on the death day and night. Besides holding kenduri arwah, some of Malay community has invented several practices related to death, which in fact are bidaah practices which are prohibited, and should be avoided. One of them is bringing the titles of the dead to the grave. This is a banned bidaah, as it resembles the death ceremony of nonMuslims, besides wasting the properties andbeing arrogant with the titles owned. One of them also is building monument on the grave and building a dome on it and wailing the death.

In a hadis narrated by Jarir bin Abdullah al-Bajali, he said that:

Means: We consider the assembly at the dead's house and preparing food to be included as wailing.

(Sahih: Majah:1601)

However, it is not denied that some of the scholars in Malaysia and Nusantara (archipelago) who permit feast of death and tahlil with the objective of praying for the dead and delivering the reward of deed in the conditions that the feast is not considered compulsory, without utilising the orphans' properties, without holding it on certain nights, without gazetting that Prophet p.b.u.h. urged Muslims to do it and it must only be related to custom of Malay community only.

To help delivering the reward of deed to the dead, it can be done through praying and giving alms on behalf of the dead and no need for a specific ceremony for it. In a hadis narrated by Uthman bin Affan r.a explaining, Rasululah p.b.u.h. said: 
INTERNATIONAL JOURNAL OF ACADEMIC RESEARCH IN BUSINESS AND SOCIAL SCIENCES

Vol. 8, No. 10, Oct. 2018, E-ISSN: 2222-6990 (C) 2018 HRMARS

Means: When prophet p.b.u.h. finished burying the dead, he would stand beside the grave and said,; pray for forgiveness for your brother and his firmness to answer the questions, as he is now being questioned.

(Sahih: Dawud:2804)

Allah s.w.t said on the hope of dying people that they will be given a chance to have a life again.

Means: And spend (donate) some of the bounties that We have given to you before the death comes to one of you, (if not) so he (at that time) will beg while saying: "O my god! How good if You delay the arrival of my death - to some time a little bit more, so that I can give alms and I can become one of pious people".

(al-Munafiqun 63:10)

Islam prohibits the building of any decoration or tall building on the grave. Indeed, leveling the grave at the ground level is more encouraged than lifting it up to a span. Abu Dawud dan alHakim narrated with an authentic sanad (chain of narrators) that the graves of Rasulullah and his two companions, Abu Bakar and Umar al-Faruq r.a were in that form. While the narration of al-Bukhari from Sufyan al-Nammar which stated that he saw the grave of Rasulullah was lifted; to answer, it is glad to be said that, as stated by al-Baihaqi, in the early stage, Rasulullah's grave was at the ground level. But after the wall of Rasulullah's room fell down in the era of al-Walid, it was lifted and some scholars reported that in the era of Umar bin Abd Aziz, it had just been lifted ('Asyur, 2001).

In the hadis narrated by Abu al-Hayyaj al-Asadi r.a explaining Rasulullah p.b.u.h. said to Ali bin Abi Talib r.a;

Means: Do not leave any idol except that you destroy it and do not leave any grave built with building on it except that you level it to the ground level.

(Sahih: Muslim:1609)

Grieving for 40 days in conjunction with death of a dignitary in the country, does not exist in Islam. Indeed, the only person allowed to grieve more than four months on someone's death is the wife on her husband's death. This is stated in Allah s.w.t's words:

Means: And the deceased people among you, and they left the wives, the wives should hold themselves (beridah) for four months and ten days. Then when the period of idah has finished, there is no harm for you on what they do to themselves in a good way (permitted by sharia). And (remember), Allah always knows deeply of what you do.

(al-Baqarah 2:234)

It is allowed to grieve for relatives' death (other than the death of husband, either the death of father, mother, brothers, children and others) for three days and not more than that (prohibited). The limit of three days is allowed as sharia considers the condition of soul and behavior of a human 
INTERNATIONAL JOURNAL OF ACADEMIC RESEARCH IN BUSINESS AND SOCIAL SCIENCES Vol. 8, No. 10, Oct. 2018, E-ISSN: 2222-6990 @ 2018 HRMARS

which obviously mourns in the loss of a loved one leading to loss of appetite, grooming, wearing nice clothes and others. Due to that, Ummu Habibah and Zainab bintu Jahsyi r.a wore perfume after the mourning period. Both of them stated that they wore perfume not because of a need. This shows that the sign of sorrow was still in them, but sharia prohibits them from grieving of more than three days. At the moment, there was nothing which was lenient for them except to obey the commandment of religion (al-Asqalani, 1379H).

The law of three days period is not mandatory (wajib) but permissible (harus) only in which it is allowed only for three days only. If a woman ignores it and instantly goes for grooming and nice appearance in front of the husband to entertain him, it is better.

\section{Conclusion}

Malay community is rich with a lot of customs. The existence of the customs pictures the wisdom of Malay community in enforcing routines practised among them to produce a prosperous, harmony and peaceful community. Malay customs have undergone the islamisation process since the era of Melaka Malay kingdom. But it was not comprehensive. In the customs regarding visit and coming to other's house practised in Malay community, such as memberi salam (addressing regards), taking off shoes before entering the house, introducing one's self and bowing asa sign of respect while shaking hands, lowering the head while passing by a group or gathering of people, lowering the head while extending a hand, the guest and the houseowner sitting with legs crossed, not refusing the food prepared by the houseowner, the girl needs to scoop the rice into the plate of elder people, giving way to elder people to the food first then the younger people, getting the closer food and not reaching for farther food which is difficult to reach, not raising annoying topics during the conversation which will distort the appetite or cause a quarrel to the guest or others, all of them are good and noble customs which do not contradict with Islam and sunnah (traditions) of Prophet P.B.U.H. and they shall be practised and continued.

Customs regarding pregnancy such as cannot insult or telling on deformity, cannot hot, abuse or injure animal, cannot use nail, chisel, hook or slaughter animal, cannot see bizarre things, cannot eat squid, cannot consume sugar cane and coconut drink and pineapple, cannot stare at eclipse and cannot sleep until midday are means of taking care of pregnant mothers and their gestations, from negative practices which involve physical and spiritual aspects that can affect the mother and the carried baby.

However, the risks that may rise from practicing the prohibited practices are still ambiguous and unacceptable. For example, insulting other people will cause the baby to deform, nailing and chiseling will cause cleft lip, seeing bizarre things will cause resemblance (kenan), sleeping in midday will cause the baby's head to swell, eating squid will cause the baby to be suffocated by the umbilical cord and others. These beliefs need to be referred to the experts.

Customs regarding birth such as stomach rolling, hanging thorny pine leaf under the house and crossing chalk at certain places in the house of pregnant woman and the placenta cannot be 
buried at 12 at noon sharp as it may lead to a stubborn kid, do contradict with teachings of Islam and should be avoided.

Customs related to marriage such as the future couple should not go out together in 40 days before the marriage ceremony, the couple is prohibited from going out freely to prevent black magic or voodoo, the custom of spying (merisik), proposal and henna wearing are good customs and should be continued, while the custom of sprinkling (merenjis) or performing tepung tawar should be avoided as it resembles the practice done by Hindu embracers although the person doing it is not intending of following the ritual.

Custom related to death is such as sprinkling flower-mixed water onto the grave after the burying of the body. This custom does not contradict with Islam if it is done to tighten the soil structure of the grave and is not intended to help the dead. The custom of holding feast of death of tahlil ceremony of the $1^{\text {st }}, 3^{\text {rd }}, 44^{\text {th }}$ and $100^{\text {th }}$ day, building decoration on the grave such as marble and widening the the grave after 100 days of death and mourning for 40 days, and custom of wearing certain clothes on the death of dignitary, should be avoided and for the substitute, the practices closer to sunnah should be performed such as lifting the grave to a span height, submitting a lot of prayer, giving alms on behalf of the dead and not mourning for the death of dignitary of more than three days.

However, it is not denied that some of the customs is not practised anymore by Malay community nowadays such stomach rolling, putting thorny pine leaf under the pregnant woman'shouse to avoid disturbance by mystical creatures and going out before 40 days of marriage ceremony. This is due to the understanding of Islamic teachings which is improving among the community and the improvement of health care and good lifestyle among future wedding couple and pregnant woman.

This writing however is more to an early review. A more serious field study at the level of Master and Doctorate should be done to observe the extent of Malay customs to adhere or contradict to Islamic teachings. It needs views from experts and the practitioners of Malay custom itself. With that, good customs will be resumed and the customs contradicting with Islam will be islamised or alternated with more suitable ones that conform to the holy Islamic teachings.

\section{Corresponding Author}

Basri Ibrahim, Jamalullail Professorial Chair, Global Wisdom Academy, Universiti Islam Malaysia, Cyberjaya, Malaysia.

Email:drbasr67@gmail.com.

\section{Acknowledgement}

Special thanks to the GWA, Universiti Islam Malaysia, Cyberjaya for funding the research. 
INTERNATIONAL JOURNAL OF ACADEMIC RESEARCH IN BUSINESS AND SOCIAL SCIENCES

Vol. 8, No. 10, Oct. 2018, E-ISSN: 2222-6990 ㄷ 2018 HRMARS

\section{References}

Al-Abadi, M.S.H. (1415H). Aun al-Ma'bud Syarah Sunan Abi Dawud. Beirut: Dar al-Kutub Al-

'Ilmiyyah.

Abdullah, Y. (2006). "Beberapa Aspek 'Urf Fasid dalam Budaya Melayu dan Kesannya Terhadap Hukum” dlm. Md. Saleh Hj. Md. (ed.), Hukum Islam dan Budaya Tempatan. Kuala Lumpur: Universiti Malaya.

Ahmad, H. (n.d). Musnad Ahmad. Http://www.al-Islam.com.

Anis, H.O. (2014), Pantang Larang Dalam Kalangan Orang Melayu: Analisis Dari Perspektif Teori Spb4k, Jurnal Antarabangsa Dunia Melayu, vol. 1. no. 1. Universiti Pendidikan Sultan Idris.

Al-Asqalani, A.A.I.H. (1379H). Fath al-Bari Syarah Sahih al-Bukhari. vol. 9. Egypt: al-Maktabah alSalafiyyah.

Asyur, A.I. (2001). al-Figh al-Muyassar Fi al-'Ibadat Wa al-Mu'amalat. vol. 1-2. Damsyiq:Dar al-Khayr. Al-Baihaqi, A.B.M.H. (1344H). al-Sunan al-Kubra. Haidarab: Majlis Da'irah al-Ma'arif al-Nizamiyyah.

Al-Bukhari, M.I. (1422H). Sahih al-Bukhari. Dar Tawq al-Najah.

Al-Bukhari, M.I. (1989). al-Adab al-Mufrad. Beirut: Dar al-Basya'ir al-Islamiyyah.

AbuDawud, A.D.S. (2009). Sunan Abi Dawud. Dar al-Risalah al-'Alamiyyah.

Hukum Melakukan Upacara “ Tepung Tawar, http://www.al-ahkam.net.20. November 2003.

Irma, M. (2016). 27 Adat Resam Dan Pantang Larang Melayu, Orang Masih Buat Lagi Ke?. https://soscili.my. 24.Jun. 2018.

Kamarudin, A \& Liki, H. (2008). Adat, pantang larang, petua dan fatwa dalam masyarakat Melayu, in. isu-isu Budaya Dalam pembangunan Sosial, Sintok: Universiti Utara Malaysia.

Kamus Dewan bahasa dan pustaka (2007). Kuala Lumpur: Dewan Bahasa Dan Pustaka.

IbnMajah, A. M. Y. (2004). Sunan Ibn Majah. Dar al-Risalah al-'Alamiyyah.

Al-Mawsu'ah al-Fiqwhiyyah. (1983). vol. 32. Kuwait: Wazarah al-Awqaf Wa al-Syu'un al-Islamiyyah.

Muslim, H. (n.d). Sahih Muslim. Beirut: Dar Ihya' al-Turath al-'Arabi.

Norhaslina, O. (2004). Adat Melayu Sebagai Sumber Hukum: Penilaian Dari Perspektif Teori al-'Urf Wa al-'Adah. Tesis Master. Kuala Lumpur: Jabatan Fiqh Dan usul, Akademi Pengajian Islam, Universiti Malaya.

Ramli, W. M. (1999). Pantang Larang Orang Melayu Tradisonal. Kuala Lumpur: Utusan Publication \& Distributors Sdn Bhd.

Rosli, S. (2005). Teromba. Negeri Sembilan: Jabatan Kebudayaan Kesenian dan Warisan Negeri Sembilan.

Samhis, S. (2016). 8 Pengertian Adat Istiadat Menurut Para Ahli Terlengkap, http://www.gurupendidikan.co.id, 24.Jun. 2018.

Al-San'ani, M.I. (1960). Subul al-Salam. Egypt: Maktabah Mustafa al-Babi al-Halabi. Wahab

Al-Tirmizi, M.I. (n.d). Sunan al-Tirmizi. http:www.al-Islam.com.

Tonel, T. (1920). Adat-Istiadat Melayu. Naskah tulisan tangan huruf Melayu Arab, Pelalawan.

Kadir, W.A. (2000).Tradisi dan Perubahan Norma dan Nilai Di Kalangan Orang-orang Melayu. Kota Baharu: Masfami Enterprise.

Ghalib, W. (2015). Seminar “Masyarakat Melayu Riau dan Kebudayaannya” Tanjung Pinang, Riau, Indonesia, 17 - 21 Julai 1985.

Yayasan K. (1973). Ensiklopedi Umum. Yogyakarta: Kanisius. 
INTERNATIONAL JOURNAL OF ACADEMIC RESEARCH IN BUSINESS AND SOCIAL SCIENCES

Vol. 8, No. 10, Oct. 2018, E-ISSN: 2222-6990 @ 2018 HRMARS

Zaidan, A.K. (1976). Usul al-Fiqh. Baghdad: Mu'assasah Qurtuba.

Zainal, K. (1996). Adat dlm. Zainal Abidin Borhan (ed). Adat Istiadat Melayu Melaka. Kuala Lumpur: Institut Kajian Sejarah Patriotisme Malaysia (IKSEP).

Al-Zuhaili, M. (2007). al-Mu'tamad Fi al-Fiqh al-Syafi'i. vol.1-5. Damsyik: Dar al-Qalam. 